\title{
Combining ability for yield and different quality traits in rice (Oryza sativa L.)
}

\author{
J. Menaka* and S. M. Ibrahim \\ Department of Plant Breeding and Genetics, Agricultural College and Research Institute, Madurai-625104 \\ (Tamil Nadu), INDIA \\ *Corresponding author. E-mail: menakrishnan@gmail.com
}

Received: April 19, 2016; Revised received: October 10, 2016; Accepted: December 7, 2016

\begin{abstract}
Gene action and combining ability for yields and quality traits were analyzed by line $x$ tester analysis in 48 crosses along with 8 lines and 6 testers to find out their usefulness in improvement of quality traits. Analysis of variance revealed that ASD 16 line and Pusa Basmati 1 and Basmati 370 testers were the good combiners for both yield and quality traits. The crosses ADT 36 / GEB 24, ASD 16 / Pusa Basmati 1, ADT 43 / Jeeragasamba, MDU 2 / Pusa Basmati 1 and MDU 5 / Improved White Ponni were identified as the good specific combiners for grain yield and some other quality characters. Dominance gene action was found to be predominant for most of the quality characters along with yield giving way for exploitation of heterosis breeding for meeting out the increasing quality preference of the consumers.
\end{abstract}

Keywords: Gene action, Gca effect, Per se, Sca effect

\section{INTRODUCTION}

Though Rice is the staple food crop of India, self sufficiency and the changing food consumption pattern of people, has diverted the attention towards quality. Also rice export from India is mostly based on Basmati where two third of the production goes for export (Ramakrishna and Degaonkar, 2016). Keeping in view this market preference, breeding for quality places emphasis on long and short slender grains of dry flaking cooking quality. The market value of the milled rice largely depends on the length and breadth of the kernel and its market preference as reported by Adilakshmi and Upendra (2014). Combining ability analysis provides information on the nature and magnitude of gene action for the traits of economic importance which helps in the identification of potential parents and cross combinations for an efficient breeding programme in crop improvement.

\section{MATERIALS AND METHODS}

Seeds of Eight high yielding cosmopolitan varieties, viz., ADT 43, CO 43, MDU 2, MDU 4, ASD 16, ADT 36, IR 20 and MDU 5 and 6 fine grained rice varieties namely Improved White Ponni, GEB 24, Jeeragasamba, Basmati 370, Pusa Basmati 1 and ADT 41 were sown in nursery in a staggered manner to get synchrony with flowering. Thirty day old seedlings were transplanted in the main field with a spacing of $30 \mathrm{X} 20 \mathrm{~cm}$ and crossing was carried out in L X T fashion. The $F_{1}$ s obtained from those crosses and their parents were raised in a Randomized Block Design with two replications. Each plot consisted of a single row of $3 \mathrm{~m}$ with a spacing of $20 \mathrm{~cm}$ between rows and $15 \mathrm{~cm}$ between plants. Recommended cultural and plant protection schedules were followed. Observations were recorded on five randomly chosen plants in each replication for panicles per plant, panicle length, grains per panicle, grain weight, milling per cent, head rice recovery, kernel length, length / breadth ratio, linear elongation ratio, volume expansion ratio, alkali spreading value, gel consistency, amylose content and single plant yield. The seeds were dehulled using Satake Grain Testing Mill and the qualitative characters were estimated using the standard procedures: Milling percentage and head rice recovery (Ghosh et al., 1971), kernel length and kernel breadth before cooking and after cooking (Ramaiah classification, 1969), linear elongation ration (IARI, 1980), volume expansion ratio (Juliano et al., 1965), Alkali spreading value (Little et al., 1958), gel consistency (Cagampange et al., 1973) and amylose content (Juliano, 1971). The combining ability analyses were subjected to analysis of variance appropriate for Line $\mathrm{x}$ Tester crossing design as suggested by Kempthorne (1957).

\section{RESULTS AND DISCUSSION}

The analysis of variance revealed highly significant differences among lines, testers and line $\mathrm{x}$ tester for all the character studies of rice indicating the presence of genetic variability in the experimental material (Table 1). Among the lines each line was found to be a good combiner for individual traits. However ASD 16 was found to be the best combiner since it exhibits good gca for 9 out of 13 characters. Pusa Basmati 1 and Basmati 370 were found to be best among testers for both 
J. Menaka and S. M. Ibrahim / J. Appl. \& Nat. Sci. 8 (4): 2298-2304 (2016)

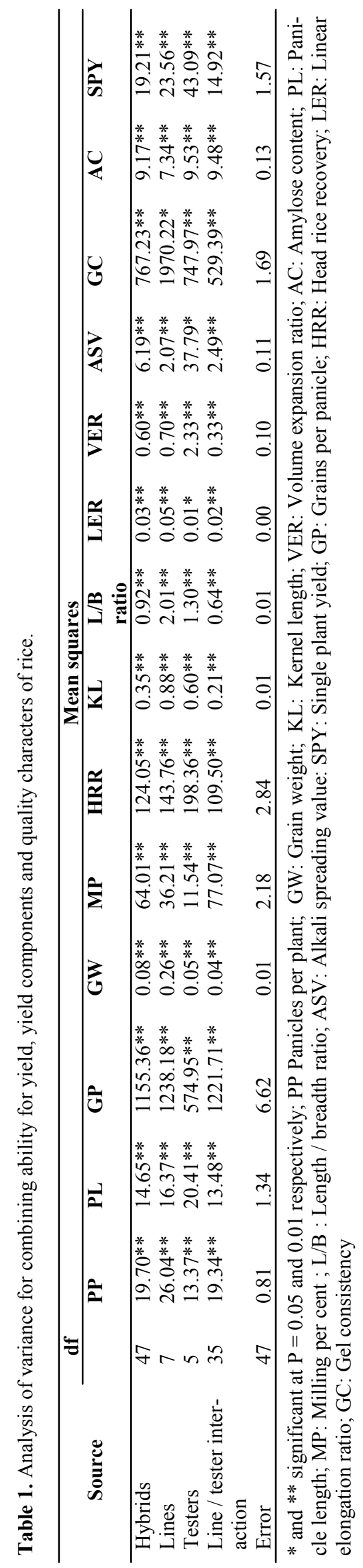

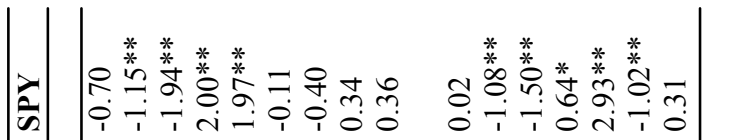

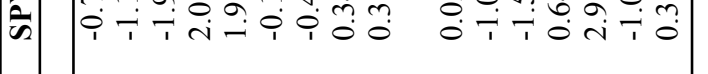
孔| : -

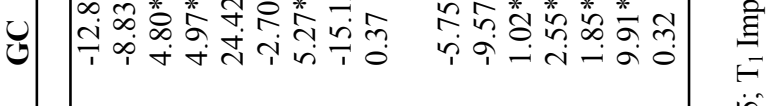
苟 畨 異 일

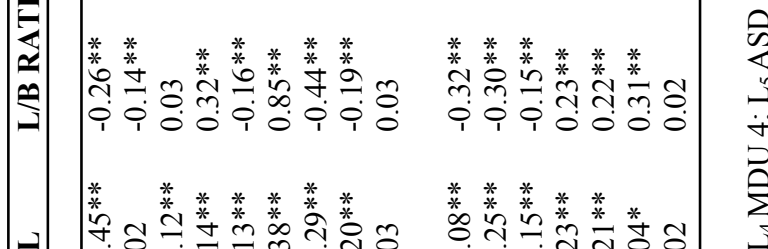

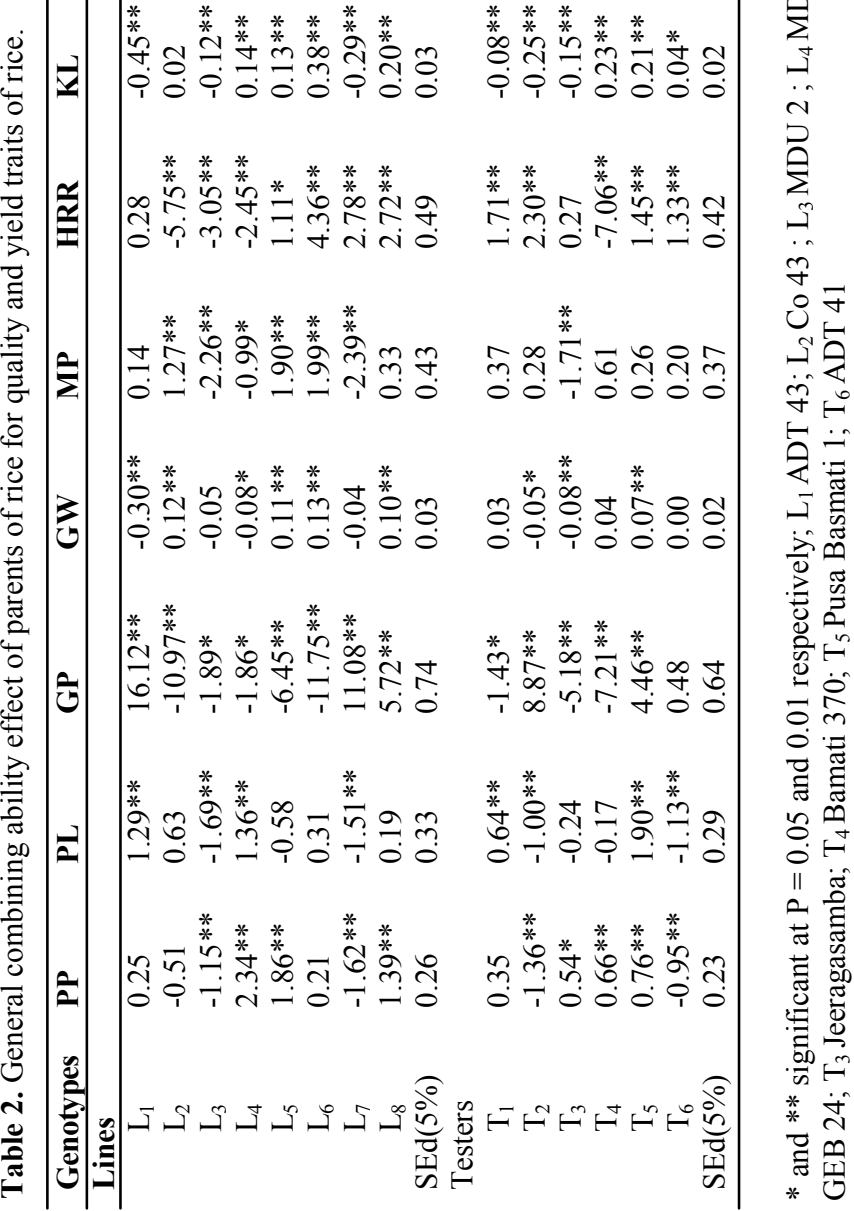


yield and quality traits.

Partitioning of the combining ability variances into fixable additive genetic variance and non-fixable dominance variance indicated that both additive and dominant gene action play a significant role in controlling the expression of all the traits. Dominance gene action was predominant for all the five quantitative characters viz., panicles per plant, panicle length, grains per panicle, grain weight and single plant yield. Predominance of non additive gene action for yield and yield related traits was also reported by Hasan et al. (2015), Waza et al. (2015), Ghosh et al. (2013), Srivastava et al. (2012), Saidaiah (2010) and Jayasudha and Sharma (2009). Also in case of panicle length and grain weight the additive gene action was found to be lower than dominant gene action as reported by Hasan et al. (2015). Dominant gene action seems to be more important for the expression of physico-chemical traits like head rice recovery, kernel length, length / breadth ratio, linear elongation ratio, volume expansion ratio, alkali spreading value, gel consistency and amylose content which was in agreement with the findings of Adilakshmi and Upendra (2014) and Thakare et al. (2013). Milling percent also had higher SCA variance as reported by Waza et al. (2015) whereas Alkali spreading value was the single character which exhibited additive genetic variance in contrast to their reports.

General combining ability effects of parents: The potential of a variety is judged by comparing the mean performance and combining ability effects of the parents (Singh et al., 1985). Combining ability analysis seems to be the most reliable and quickest method of understanding the genetic nature of quantitatively inherited characteristics (Sharma et al., 2012). Gilbert (1958) suggested that the parents with high mean performance would be much useful in producing better offspring in any breeding programme. According to Sprague and Tatum (1942) the parents having high gca effects could be useful, since the $g c a$ effect is due to additive gene action which is fixable.

Among the testers Pusa Basmati 1 was identified as the best parent based on both per se and gca for eight traits namely panicle length, grain weight, kernel length, length / breadth ratio, volume expansion ratio, alkali spreading value, gel consistency and amylose content. It was followed by ADT 41 for kernel length, length / breadth ratio, volume expansion ratio, alkali spreading value and gel consistency (Table 2). This was observed by Faiz et al. (2006). However MDU 5 showed desirable performance for three characters namely grain weight, kernel length and alkali spreading value followed by ADT 36 for head rice recovery and amylose content; ASD 16 for grain weight and milling per cent and MDU 2 for linear elongation ratio and gel consistency. Among the lines there was no parallelism between per se performance and gca effects as ob- 
Table 4. Hybrids for recombination breeding for quality and yield traits in rice.

\begin{tabular}{|c|c|c|c|}
\hline Characters & $\begin{array}{l}\text { Good combining } \\
\text { line }\end{array}$ & Good combining tester & $\begin{array}{l}\text { Promising crosses for recombina- } \\
\text { tion breeding }\end{array}$ \\
\hline Panicles per plant & $\begin{array}{l}\text { MDU } 4 \\
\text { ASD } 16\end{array}$ & Jeeragasamba & - \\
\hline & & Pusa Basmati 1 & \\
\hline Panicle length & $\begin{array}{l}\text { ADT } 43 \\
\text { MDU } 4\end{array}$ & $\begin{array}{l}\text { Improved White Ponni } \\
\text { Pusa Basmati } 1\end{array}$ & $\begin{array}{l}\text { ADT } 43 \text { / Improved White Ponni } \\
\text { - }\end{array}$ \\
\hline Grains per panicle & $\begin{array}{l}\text { ADT } 43 \\
\text { IR } 20 \\
\text { MDU } 5\end{array}$ & $\begin{array}{l}\text { GEB } 24 \\
\text { Pusa Basmati } 1\end{array}$ & \\
\hline Grain weight & $\begin{array}{l}\text { CO } 43 \\
\text { ASD } 16 \\
\text { ADT } 36 \\
\text { MDU } 5\end{array}$ & Pusa Basmati 1 & $\begin{array}{l}\text { ASD } 16 \text { / Pusa Basmati } 1 \\
\text { ADT } 36 \text { / Pusa Basmati } 1 \\
\text { MDU } 5 \text { / Pusa Basmati } 1\end{array}$ \\
\hline Head rice recovery & $\begin{array}{l}\text { ASD } 16 \\
\text { ADT } 36 \\
\text { IR } 20 \\
\text { MDU } 5\end{array}$ & $\begin{array}{l}\text { Improved White Ponni } \\
\text { GEB } 24 \\
\text { Pusa Basmati } 1 \\
\text { ADT } 41\end{array}$ & IR 20 / ADT 41 \\
\hline Kernel length & $\begin{array}{l}\text { MDU } 4 \\
\text { ASD } 16 \\
\text { ADT } 36\end{array}$ & $\begin{array}{l}\text { Basmati } 370 \\
\text { Pusa Basmati } 1 \\
\text { ADT } 41\end{array}$ & $\begin{array}{l}\text { ASD } 16 \text { / Pusa Basmati } 1 \\
\text { ASD } 16 \text { / ADT } 41 \\
\text { ADT } 36 \text { / Basmati } 370 \\
\text { MDU } 5 \text { / Pusa Basmati } 1\end{array}$ \\
\hline Length / breadth ratio & $\begin{array}{l}\text { MDU } 4 \\
\text { ADT } 36\end{array}$ & $\begin{array}{l}\text { Basmati } 370 \\
\text { Pusa Basmati } 1 \\
\text { ADT } 41\end{array}$ & \\
\hline Linear elongation ratio & $\begin{array}{l}\text { ADT } 43 \\
\text { MDU } 2\end{array}$ & $\begin{array}{l}\text { GEB } 24 \\
\text { Pusa Basmati } 1\end{array}$ & - \\
\hline Volume expansion ratio & ADT 43 & $\begin{array}{l}\text { Basmati } 370 \\
\text { Pusa Basmati } 1 \\
\text { ADT } 41\end{array}$ & $\begin{array}{l}\text { ADT } 43 \text { / Basmati } 370 \\
\text { ADT } 43 \text { /ADT } 41\end{array}$ \\
\hline Alkali spreading value & $\begin{array}{l}\text { ADT } 43 \\
\text { ADT } 36 \\
\text { MDU } 5\end{array}$ & $\begin{array}{l}\text { Basmati } 370 \\
\text { Pusa Basmati } 1 \\
\text { ADT } 41\end{array}$ & $\begin{array}{l}\text { ADT } 43 \text { / Pusa Basmati } 1 \\
\text { ADT } 43 \text { / ADT } 41 \\
\text { ADT } 36 \text { / Basmati } 370 \\
\text { ADT } 36 \text { / Pusa Basmati } 1 \\
\text { ADT } 36 \text { / ADT } 41 \\
\text { MDU } 5 \text { / Basmati } 370 \\
\text { MDU } 5 \text { / ADT } 41\end{array}$ \\
\hline Gel consistency & $\begin{array}{l}\text { MDU } 2 \\
\text { MDU } 4 \\
\text { ASD } 16 \\
\text { IR } 20\end{array}$ & $\begin{array}{l}\text { Jeeragasamba } \\
\text { Basmati } 370 \\
\text { Pusa Basmati } 1 \\
\text { ADT } 41\end{array}$ & ASD $16 /$ ADT 41 \\
\hline Amylose content & $\begin{array}{l}\text { CO } 43 \\
\text { MDU } 2 \\
\text { ASD } 16 \\
\text { ADT } 36\end{array}$ & $\begin{array}{l}\text { Improved White Ponni } \\
\text { Basmati } 370 \\
\text { Pusa Basmati } 1 \\
\text { ADT } 41\end{array}$ & MDU 2 / Basmati 370 \\
\hline Grain yield & $\begin{array}{l}\text { MDU } 4 \\
\text { ASD } 16\end{array}$ & $\begin{array}{l}\text { Basmati } 370 \\
\text { Pusa Basmati } 1\end{array}$ & \\
\hline
\end{tabular}

served by Adilakshmi and Upendra (2014). In contrary Sharma et al. (2012) reported that the per se performance of the parent and their gca effects for all the characters were almost in close correspondence, which indicated that the per se performance of the parent for these traits could possibly be taken as a criterion for selection of parent. Hence in this study superior lines were be selected based on per se since the per se per- formance is the realized value while gca effects are merely estimates. The parents can be considered for further exploitation if they possess higher order of per se performance. Based on this criterion the lines MDU 5, ASD 16, ADT 36 and MDU 2 were selected as the best lines for yield and quality traits.

Specific combining ability of the hybrids: According to Sprague and Tatum (1942) the sca effects are due to 
Table 5. Hybrids for heterosis breeding for quality and yield traits in rice.

\begin{tabular}{|c|c|}
\hline Characters & Hybrids \\
\hline Panicles per plant & $\begin{array}{l}\text { MDU4 / Jeeragasamba, MDU4 / Pusa Basmati 1, ASD } 16 \text { / Improved White Ponni, ASD } 16 \text { / Pusa } \\
\text { Basmati } 1\end{array}$ \\
\hline Panicle length & - \\
\hline Grains per panicle & $\begin{array}{l}\text { CO } 43 \text { / Pusa Basmati 1, MDU } 2 \text { / Pusa Basmati 1, MDU } 4 \text { / Improved White Ponni, ASD } 16 \text { / } \\
\text { Jeeragasamba, ADT } 36 \text { / GEB 24, IR } 20 \text { / Jeeragasamba, MDU } 5 \text { / GEB } 24\end{array}$ \\
\hline Grain weight & CO 43 / Pusa Basmati 1 \\
\hline Milling per cent & $\begin{array}{l}\text { CO } 43 \text { / Jeeragasamba, MDU } 2 \text { / Improved White Ponni, ADT } 36 \text { / Basmati 370, IR } 20 \text { / Basmati } \\
\text { 370, IR } 20 \text { / Pusa Basmati 1, MDU } 5 \text { / ADT } 41\end{array}$ \\
\hline Head rice recovery & $\begin{array}{l}\text { ADT } 43 \text { / Improved White Ponni, ADT } 43 \text { / GEB 24, ADT } 43 \text { / Jeeragasamba, MDU } 2 \text { / GEB } 24 \text {, } \\
\text { MDU } 2 \text { / Pusa Basmati 1, MDU } 4 \text { / Improved White Ponni, ASD } 16 \text { / Pusa Basmati 1, ASD } 16 \text { / } \\
\text { ADT } 41 \text {, ADT } 36 \text { / GEB 24, ADT } 36 \text { / Basmati 370, IR } 20 \text { / Basmati 370, IR } 20 \text { / Pusa Basmati 1, } \\
\text { MDU } 5 \text { / Improved White Ponni, MDU } 5 \text { / Jeeragasamba. }\end{array}$ \\
\hline Kernel length & - \\
\hline Length / breadth ratio & MDU 2 / ADT 41, MDU 4 / Basmati 370, ADT 36 / Pusa Basmati 1, ADT 36 / ADT 41 \\
\hline Linear elongation ratio & $\begin{array}{l}\text { ADT } 43 \text { / Pusa Basmati 1, ADT } 43 \text { / ADT 41, CO } 43 \text { / Jeeragasamba, MDU } 2 \text { / Improved White } \\
\text { Ponni, ADT } 36 \text { / GEB } 24\end{array}$ \\
\hline $\begin{array}{l}\text { Volume expansion } \\
\text { ratio }\end{array}$ & - \\
\hline Alkali spreading value & - \\
\hline Gel consistency & $\begin{array}{l}\text { ADT } 43 \text { / Jeeragasamba, MDU } 2 \text { / Improved White Ponni, MDU } 2 \text { / Basmati 370, MDU } 2 \text { / Pusa } \\
\text { Basmati 1, MDU } 2 \text { / ADT 41, MDU } 4 \text { / Jeeragasamba, MDU } 4 \text { / ADT 41, ASD } 16 \text { / Improved } \\
\text { White Ponni, ASD } 16 \text { / GEB 24, ASD } 16 \text { / Jeeragasamba, ASD } 16 \text { / Basmati 370, ASD } 16 \text { / Pusa } \\
\text { Basmati 1, ADT } 36 \text { / GEB 24, IR } 20 \text { / Jeeragasamba, IR } 20 \text { / Basmati 370, IR } 20 \text { / ADT } 41\end{array}$ \\
\hline Amylose content & MDU 2 / Pusa Basmati 1, ASD 16 / Pusa Basmati 1 \\
\hline Single plant yield & $\begin{array}{l}\text { MDU } 2 \text { / Pusa Basmati 1, MDU } 4 \text { / Basmati 370, MDU } 4 \text { / Pusa Basmati 1, ASD } 16 \text { / Basmati 370, } \\
\text { ASD } 16 \text { / Pusa Basmati 1, MDU } 4 \text { / Improved White Ponni, }\end{array}$ \\
\hline
\end{tabular}

non-additive gene action. In the present study significant $s c a$ effect was exhibited for nine characters namely panicles per plant, panicle length, milling per cent, head rice recovery, linear elongation ratio, volume expansion ratio, alkali spreading value, gel consistency and single plant yield by the hybrid ADT 36 / GEB 24. This was followed by the hybrid ASD 16/ Pusa Basmati 1 which had significant sca for eight characters namely panicles per plant, head rice recovery, length / breadth ratio, volume expansion ratio, alkali spreading value, gel consistency, amylose content and single plant yield. The hybrid ADT 43 / GEB 24 was found to be best for grains per panicle, milling per cent, head rice recovery, kernel length, length / breadth ratio, gel consistency and single plant yield while ADT 43 / Jeeragasamba recorded significant $s c a$ for panicles per plant, milling per cent, head rice recovery, kernel length, length / breadth ratio, alkali spreading value and gel consistency. The other two hybrids which had recorded positive $s c a$ for seven characters are MDU 2 / Pusa Basmati 1 and MDU 5 / Improved White Ponni. MDU 2 / Pusa Basmati 1 was found to be best for panicles per plant, grains per panicle, milling per cent, head rice recovery, gel consistency, amylose content and single plant yield. MDU 5 / Improved White Ponni showed significant positive sca for panicles per plant, grains per panicle, head rice recovery, alkali spreading value, gel consistency and single plant yield (Table 3 ). Most of the crosses having significant $s c a$ effects recorded higher per se performance. Thus all these crosses were found to be outstanding with respect to grain yield and quality traits.

Hybrids for recombination breeding: In case of hybrids with significant sca effects, selection in early segregating generations is likely to fail as the sca effects mask the true performance of the selected parents. As suggested by Nadarajan and Sree Rangaswamy (1990) and Srivastava et al. (2012) it will be useful to select only those hybrids having parents with high gca effects with non significant sca effects for recombination breeding, since it is likely to throw segregants with favourable genes derived from both the parents. In this study, evaluation of hybrids based on the above criterion revealed that the combinations ASD 16/ Pusa Basmati 1 and MDU 5 / Pusa Basmati 1 were best for grain weight and kernel length; ADT 36 / Basmati 370 for kernel length and alkali spreding value; ADT 43 / Improved White Ponni for panicle length; ASD $16 /$ ADT 41 for gel consistency and kernel length; IR 20 / ADT 41 for head rice recovery; ADT 43 / Basmati 370 and ADT 43 / ADT 41 for volume expansion ratio; MDU 2 / Basmati 370 and ASD 16 / Basmati 370 for amylose content would result in superior segregants through recombination breeding. Hence these hybrids may serve as better sources for deriving superior segregants by recombination breeding for the improvement of the respective traits (Table 4).

Hybrids for heterosis breeding: The presence of nonadditive genetic variance offers scope for exploitation of heterosis. The hybrid combinations with a higher expression of the genetic parameters namely mean and $s c a$ effects were selected for heterosis breeding. MDU 
2 / Pusa Basmati 1 was found to be best for five traits namely head rice recovery, grains per panicle, gel consistency, amylose content and single plant yield. ASD 16 / Pusa Basmati 1 was also found to be best for five traits namely panicles per plant, head rice recovery, gel consistency, amylose content and single plant yield followed by ADT 36 / GEB 24 with four traits namely grains per panicle, head rice recovery, linear elongation ratio and gel consistency. MDU 2 / Improved White Ponni was found to be best for milling per cent, head rice recovery and gel consistency. The higher sca value in these crosses indicated the presence of nonadditive genetic variance offering the scope for exploitation of heterosis. In an overall manner three hybrids namely ASD 16 / Pusa Basmati 1, MDU 2 / Pusa Basmati 1 and ADT 36 / GEB 24 were selected for heterosis breeding. But the mean performance being the actual realized value and sca being estimated the former should be given due importance as reported by Pethani and Kapoor (1984) and Saleem et al. (2010). Based on the above critera, the hybrids ASD 16 / Pusa Basmati 1, ADT 36 / GEB 24, MDU 4 / Basmati 370 and MDU 4 / ADT 41 were found to be best for most of the yield and quality traits (Table 5).

Though different lines were found to be best for different characters based on their gca and mean the line ASD 16 was found to be the best combiner followed by ADT 36 and MDU 5 whereas in case of tester Pusa Basmati 1 and Basmati 370 were found to be good. It was noticed that crosses with good sca was found to be obtained from parents that are found to be best combiners and also from parents that have poor gca as observed by Adilakshmi and Upendra (2014) and Roy and Senapati (2012). Since most of the characters exhibited non additive gene action, heterosis breeding was found to be effective to further exploit their genetic potential.

\section{Conclusion}

From this study it was noted that both additive and non -additive gene actions were important in controlling various characters though non additive gene action was found to be predominant. The best combiners Pusa Basmati 1, Basmati 370, ADT 41, MDU 5 and ADT 36 could be utilized in future breeding programme. The crosses ASD 16 / Pusa Basmati 1, ADT 36 / GEB 24, ADT 43 / GEB 24, ADT 43 / Jeeragasamba, MDU 2 / Pusa Basmati 1 and MDU 5 / Improved White Ponni could be used for exploitation of heterosis for yield, its components and quality traits.

\section{REFERENCES}

Adilakshmi, D. and Upendra, A. (2014). Combining ability analysis for quality and nutritional traits in rice. Int $J$ Farm Sci., 4(2): 15-23

Cagampange, G.B., Perez, V.P. and Juliano, B.O. (1973). A gel consistency test for eating quality of rice. J. Sci
Food and Agric., 24: 1589-1594

Faiz, F.A., Sabar, M., Awan, T.H., Ijaz, M.and Manzoor, Z. (2006). Heterosis and combining ability analysis in Basmati rice hybrids. J. Anim. Pl. Sci., 16(1-2): 56-59

Ghosh, A.K., Nanda, B.B., Govindaswami, S and Nayak, B.B. (1971). Influence of nitrogen on the physicchemical characterisitics of rice grain. Oryza, 891:87-97

Ghosh, S.C., Chandrakar, P.K., Rastogi, N.K., Sharma, D and Sarawgi, A.K. (2013). Combining ability analysis using CMS breeding system in rice. Oryza., 50 (1): 52 57

Gilbert, N.E. (1958). Diallel cross in plant breeding. Heredity, 12: 477-492

Jayasudha, S. and Sharma, D. (2009). Combining ability and gene action analysis for yield and its components in rice (Oryza sativa L.). J. Rice Res., 2 (2): 105-111

Hasan, M.J., Kulsum, M.U., Hossain, E., Hossain, M.M., Rahman, M.M.and Rahmat, N.M.F. (2015). Combining ability analysis for identifying elite parents for heterotic rice hybrids. Academia J. Agric. Res., 3(5): 070-075

IARI (1980). High yielding Basmati rice. Problems, progress and prospects. Res. Bull 30. Indian Agricultural Research Institute, New Delhi. Pp 46.

Juliano, B.O. (1971). A simplified assay for milled rice amylose. Cereal Sci. Today, 16: 334-338

Juliano, B.O., Onate, L.U., and Del Mundo, A.M. (1965). Relation of starch composition, protein content and gelatinization temperature to cooking and eating qualities of milled rice. Food Technol., 19: 116-121

Kempthorne, O. (1957). An introduction of Genetic Statistics. John wiley and Sons Inc., New York.

Little, R.R., Hilder, G.S. and Dawson, E.H. (1958). Differential effect of dilute alkali on 25 varieties of milled white rice. Cereal chem., 35: 111-126

Nadarajan, N. and Sree Rangaswamy, S.R. (1990). Study of heterosis and combining ability in Gossypium hirsutum L. Indian J. Agric. Res., 35(3): 186-189

Pethani, K.V. and Kapoor, R.L. (1984). Combining ability and its interaction with environment for grain yhield in pearl millet. Indian J. Agric. Sci., 54:87-92

Ramaiah, K. (1969). The morphological and varietal characters of the rice plant. Technical Bulletin 4, IRRI, Phillipines pp. 40

Ramakrishna, B. and Degaonkar, C.K. (2016). Rice Export from India: Trends, problems and prospects. Int. J. Res. Granthaalayah, (4) 7: 122-136

Roy, S.K. and Senapati, B.K. (2012). Combining ability analysis for grain yield and quality characters in rice (Oryza sativa). Indian J. Agric. Sci., 82 (4): 293-303

Saidaiah, P. (2010). Combining ability studies for development of new hybrids in rice over environments. $J$. Agric. Sci. 2(2): 226-233

Saleem, M.Y., Mirza, J.I. and Haq, M.A. (2010). Combining ability analysis for yield and related traits in Basmati Rice (Oryza sativa L.). Pak. J. Bot., 42(1): 627-637

Sharma, S.K., Singh, S.K., Singh, S., Kumer, V., Singh, A. and Nandan, R. (2012). Combining ability analysis for yield and its components in hybrid rice. Oryza Vol. 49 (3): 171-177

Singh, R.S., Singh, O.N. and Chaudhary, R.K. (1985). Combining ability for yield in Indian mustard. Indian $J$. Agric. Sci., 55: 240-242

Sprague, G.F. and Tatum, LA. (1942). General versus spe- 
J. Menaka and S. M. Ibrahim / J. Appl. \& Nat. Sci. 8 (4): 2298-2304 (2016)

cific combining ability in single crosses of corn. J Amer Soc Agron 34: LA. 1942. General versus specific combining ability in single crosses of corn. J. Amer. Soc. Agron., 34: 53-932

Srivastava, A.K., Jaiswal, H.K. and Agrawal, R.K. (2012). Combining ability analysis for yield and quality traits in indigenous aromatic rice. Oryza, 49 (4): 251-257
Thakare, I.S., Mehta, A.M., Patel, J.S. and Takle, S.R. (2014). Combining ability analysis for yield and grain quality traits in rice hybrids. J. Rice Res., 3(1): 1-5

Waza, S.A., Jaiswal, H.K., Sravan, T., Priyanka, K., Bano, D.A and Ved, P.R. (2015). Combining ability analysis for various yield and quality traits in rice (Oryza sativa L.). J. App. Nat. Sci., 7 (2): 865- 873 